\title{
Legally Sculpting a Melting Arctic: States, Indigenous Peoples and Justice in Multilateralism
}

\author{
Sabaa Ahmad Khan
}

This Chapter draws attention to the interface of multilateralism and international Indigenous rights enshrined in the United Nations Declaration on the Rights of Indigenous Peoples (UNDRIP). ${ }^{1}$ While there is no universal understanding of multilateralism, definitions have been developed in international relations theory. Keohane defines multilateralism as 'the practice of coordinating national policies in groups of three or more states, through ad hoc arrangements or by means of institutions.'2 Ruggie argues that in addition to this quantitative aspect, what makes multilateralism a distinctive form of coordination is that it takes place 'on the basis of certain principles of ordering relations' ${ }^{3}$ between the states involved. Building on these earlier definitions and taking account of the role of non-state actors in multilateralism, Bouchard and Peterson conceive '21st century multilateralism' as 'three or more actors engaging in voluntary and (essentially) institutionalised international cooperation governed by norms and principles, with rules that apply (by and large) equally to all states. ${ }^{4}$

The present work engages with the practice of contemporary multilateralism in the context of the negotiation and implementation of multilateral

1 United Nations Declaration on the Rights of Indigenous Peoples, G.A. Res. 61/295, U.N. Doc. A/RES/61/295 (Sept. 13, 2007). This Chapter is based on ideas first developed by the author in Sabaa A. Khan, 'Rebalancing state and Indigenous sovereignties in international law: An Arctic lens on trajectories for global governance' (2019) 32(4) Leiden Journal of International Law, 675 .

2 Robert O. Keohane, 'Multilateralism: An Agenda for Research' (1990) 45 International Journal, 731 .

3 John G. Ruggie, 'Multilateralism: The Anatomy of an Institution' (1992) 46 (3) International Organization, 561,567 .

4 Caroline Bouchard and John Peterson, Conceptualising Multilateralism: Can We All Just Get Along? (2011), MERCURY E-paper No. 1, 10, available at http://mercury.uni-koeln.de/filead$\mathrm{min} /$ user_upload/E-paper_no1_r2o1o.pdf (accessed 17/4/20).

(C) SABAA AHMAD KHAN, 2021 | DOI:10.1163/9789004424159_007

This is an open access chapter distributed under the terms of the CC BY-NC-ND 4al dicensered Khan - 9789004424159 
agreements as they relate to Indigenous Peoples. ${ }^{5}$ It addresses the practice of multilateralism involving states and Indigenous Peoples in the context of Arctic climate change. Examining specific international legal instruments and institutions relevant to Arctic climate change, I explore the scope of Arctic Indigenous Peoples' participation in decision-making processes within these international legal spheres, against the backdrop of the UNDRIP. This Chapter argues that international Indigenous rights challenge the participational closure of these multilateral regimes with respect to their rule-making processes. Furthermore, standards embodied in the UNDRIP have implications for multilateralism that have yet to be fully acknowledged and put into consistent international legal praxis.

The Chapter is divided into three main parts. Part 2 introduces the participational features of contemporary multilateralism. It begins with a discussion of state and non-state actors in contemporary multilateralism from which emerges the notion of 'justice in multilateralism'. Part 3 turns to the question of what justice in multilateralism means for Indigenous Peoples. Underscoring the historical injustice of Indigenous Peoples' exclusion from the international community, this Part highlights the implications of the development of international Indigenous rights for contemporary multilateralism. Looking at the evolution of Indigenous Peoples' participation in the international climate regime and within the International Maritime Organization, I draw attention to how different international legal and institutional spaces engage Indigenous Peoples and states in the collective craft of world-making. Exploring the practice of multilateralism in the context of Arctic climate change brings to light enduring representational inequalities engrained in negotiations over the 'global' Arctic, prompting further reflection on what it means to seek justice in multilateral law-making. Part 4 turns to the Inuit Circumpolar Council and the Arctic Council as examples of international actors pushing forward an

5 A widely cited working definition of the concept of Indigenous Peoples endorsed by Indigenous representatives is the definition advanced by Special Rapporteur of the SubCommission on Prevention of Discrimination and Protection of Minorities, Jose R. Martinez Cobo: 'Indigenous communities, peoples and nations are those which, having a historical continuity with pre-invasion and pre-colonial societies that developed on their territories, consider themselves distinct from other sectors of the societies now prevailing on those territories, or parts of them. They form at present non-dominant sectors of society and are determined to preserve, develop and transmit to future generations their ancestral territories, and their ethnic identity, as the basis of their continued existence as peoples, in accordance with their own cultural patterns, social institutions and legal system.' Jose R. Martinez Cobo, Study of the Problem of Discrimination Against Indigenous Populations UN Doc. E/CN.4/Sub.2/ 1986/7 and Add. 1-4. [379-382]. See also Secretariat of the Permanent Forum on Indigenous Issues, The Concept of Indigenous Peoples UN doc. UN PFII/2004/Ws.1/3. 
environmental multilateralism that brings international relations out of the statist lens and closer to the fulfillment of international Indigenous rights.

Historically, Arctic Indigenous sovereignty was systematically undermined in the process of Arctic resource development. Following European Arctic exploration in the 17th century, Polar resource development was exclusively defined by Europeans and subsequently North American states for two centuries, becoming a vehicle for 'the making of the Westphalian nation-state system.' Arctic Indigenous authority over land and resources was acknowledged insofar as it advanced the Euro-American economic projects of Polar exploitation and colonization. Expedition commander William Kennedy's late 19th century account of Arctic 'exploration' depicts Arctic Indigenous Peoples as instrumental hunters and guides, while also referring to them as a 'less advanced' people living in the 'stone and iron age. ${ }^{7}$ As Andrew Stuhl notes, '[1]ike their maps, explorers' tales about an Arctic terra incognita and savage Inuit helped southerners claim the north.'8 This historical pattern of casting aside Arctic Indigenous interests in the process of Arctic development has persisted into the 21st century. Even though international law today affirms that obtaining the free and prior informed consent (FPIC) of Indigenous Peoples in relation to regulatory measures or development projects that affect them is a fundamental aspect of securing self-determination and cultural integrity, ${ }^{9}$ the reality of Arctic development reveals that Indigenous Peoples have, for the most part, not been perceived as equal partners in economic decision-making. Consultation processes with Arctic Indigenous communities often take place only long after the overall broader strategic development plans have been established.' ${ }^{10}$

$6 \quad$ Jessica Shadian 'Of Whales and Oil: Inuit Resource Governance and the Arctic Council' (2013) 49 Polar Record, 392.

7 William Kennedy, 'Letter to the Editor of the New London Telegram' in H. W. Howgate, Polar Colonization: Memorial to Congress and Action of Scientific and Commercial Associations (Beresford, Washington DC, 1879), 111.

8 Andrew Stuhl, Unfreezing the Arctic: Science, Colonialism and the Transformation of Inuit Lands (University of Chicago Press, Chicago, 2017), 3.

9 UNDRIP, note 1, Arts. 19, 32, 10, 29, 28. Normative foundations of the requirement include Article 1 of the International Covenants. See also Committee on the Elimination of Racial Discrimination (CERD) General Recommendation No.23: Indigenous Peoples (1997). For a comparative analysis on implementations of the international duty to consult and its relationship to the FPIC in the context of Latin America, see S. J. Anaya and S. Puig 'Mitigating State Sovereignty: The Duty to Consult with Indigenous Peoples' (2017) 67 University of Toronto L. J., 435 .

10 Layla Hughes, 'Relationships with Arctic Indigenous Peoples: To what extent has prior informed consent become a norm?' (2018) 27(1) RECIEL Special Issue on Arctic Environmental Governance, 15, 26. 
Moreover, Northern extractive industry projects have often entailed aggravated risks to the self-determination of Indigenous women."

Today, we see different non-Arctic and 'near-Arctic'12 states as well as multinational firms asserting their entitlement to use and to transform Arctic space, increasingly shaping the life space of Arctic Indigenous Peoples. ${ }^{13}$ Moreover, climate change is widely acknowledged as directly threatening Arctic Indigenous Peoples' existence and forcing unprecedented challenges upon their 'cultural, spiritual, social and economic health and corresponding human rights.'14 In addition to their extensive international advocacy on the matter, Arctic Indigenous Peoples have been at the forefront of domestic and regional legal efforts demanding that governmental inaction on climate change be determined a violation of their human rights, including the right to self-determination. ${ }^{15}$

In this context of historical subjugation and contemporary existential threat, ensuring justice in Arctic multilateralism is more relevant than ever to avoid the development of international legal and cooperative frameworks that disproportionately concentrate power in state actors to the detriment of Indigenous sovereignty and the right to self-determination, both concepts understood here as conveying Indigenous ownership and authority over territory

11 K. Koutouki, K. Lofts, G. Davidian 'A Rights-based Approach to Indigenous Women and Gender Inequities in Resource Development in Northern Canada' (2018) 27 (1) RECIEL, 63.

12 China self-identifies as a 'near-Arctic state' in its 2018 Arctic Policy, available at http:// english.www.gov.cn/archive/white_paper/2018/o1/26/content_28147602666o336.htm (accessed 23/12/19).

13 For example, on Asia's expanding investment in the Arctic region, see Jingchao Peng \& Njord Wegge, 'China's Bilateral Diplomacy in the Arctic' (2015) Polar Geography, 233; Non Hong 'Emerging interests of non-Arctic countries in the Arctic: a Chinese perspective' (2014) 4 The Polar Journal, 271. On China's Polar Belt and Road Initiative, see Nengye Liu 'Will China Build a Green Belt and Road in the Arctic?' (2018) 27 RECIEL Special Issue on the Arctic, 55 .

14 Inuit Circumpolar Council, Inuit Call for Action from Global Leaders at UNFCCC COP 21 in Paris, France (2015) at https://static1.squarespace.com/static/5627862ce4bo7be93cfb9461/ t/564c8521e4bood3489f7o1fa/1447855393362/Arctic+ICC.pdf (accessed 27/12/19).

15 See the Arctic Athabaskan Council, Petition to the Inter-American Commission on Human Rights seeking Relief from Violations of the Rights of Arctic Athabaskan Peoples Resulting from Rapid Arctic Warming and Melting caused by Emissions of Black Carbon by Canada, (Apr. 23, 2013). Available at: http://earthjustice.org/sites/default/files/AAC_ PETITION_13-04-23a.pdf (accessed 27/12/19); Sheila Watt-Cloutier and Inuit Circumpolar Conference (ICC), Petition to the Inter American Commission on Human Rights Seeking Relief from Violations Resulting from Global Warming Caused by Acts and Omissions of the United States, Dec. 7, 2005, Available at: http://earthjustice.org/sites/default/files/library/ legal_docs/petition-to-the-inter-american-commission-on-human-rights-on-behalf-ofthe-inuit-circumpolar-conference.pdf (accessed 27/12/19). 
and resources, at multiple scales of governance. ${ }^{16}$ One of the most important concerns is whether Arctic Indigenous Peoples are engaged as full and equal participants in the multilateral shaping of Arctic space, as required under international Indigenous rights.

\section{Contemporary Multilateralism: States and Non-States in International Law-Making}

States have always been and continue to be the dominant actors of multilateralism in all its forms, including international law-making. While their primacy in international law-making is perceived as being anchored in the concept of sovereignty, the latter is legitimated through the notion of self-determination. This core legal concept contained in the UNDRIP, ${ }^{17}$ both Covenants on human rights, ${ }^{18}$ and the Charter of the United Nations, ${ }^{19}$ draws attention to 'peoples' as

16 Sovereignty and self-determination open up vast landscapes of international legal scholarship. This Chapter engages in these discussions in a way that looks at the meaning, relevance, deployment and interpretation of these topics in the context of the rights of Indigenous Peoples. Both terms are relevant because under current international, regional and national legal systems, Indigenous Peoples' rights are discussed and framed in the language of self-determination, whereas use of the term sovereignty in relation to Indigenous Peoples captures more precisely the nation-to-nation relationship that characterizes legal realities within many states. See Erica Daes, Prevention of Discrimination and Protection if Indigenous Peoples, Final Report UN Doc. E/CN.4/Sub.2/2004/30 (13 July 2004), 18. Moreover, while the autonomy that self-determination implies can also be perceived as separatist, demanding a dissolution of existing territorial boundaries or the creation of new political structures such as in the case of decolonization or secession, this Chapter is concerned with self-determination as a fundamental human right of all peoples and, in particular, how it relates to the wrongful historical dismissal of Indigenous sovereignty under international law.

17 Self-determination is defined in similar language in both international human rights covenants and the UNDRIP. Article 3 of UNDRIP states: 'Indigenous peoples have the right of self-determination. By virtue of that right they freely determine their political status and freely pursue their economic, social and cultural development.'

18 International Covenant on Civil and Political Rights, adopted 19 December 1966, entered into force 23 March 1976, 999 UNTS 171 [ICCPR], Art.1(1): 'All peoples have the right of self-determination. By virtue of that right they freely determine their political status and freely pursue their economic, social and cultural development.'; International Covenant on Economic, Social and Cultural Rights, adopted 16 December 1966, entered into force 3 January 1976, 993 UNTS 3 [ICESCR], Art. 1(1).

19 United Nations, Charter of the United Nations, 24 October 1945, 1 UNTS XVI. Art 1(2): ‘The purposes of the United Nations are[...] To develop friendly relations among nations based on respect for the principle of equal rights and self-determination of peoples [...].' 
the root constituents of states, and consequently, of the international community. Seeing the international legal order strictly from the perspective of state sovereignty can render only partial understanding of its constitutive basis, which lies first and foremost in the relationship between states and peoples. After all, our international legal system is based on the fundamental notion that contemporary states represent the political authority of their territorial 'peoples', that these states share a universal commitment to upholding the rule of law, strengthening universal peace, respecting human rights and protecting the right to self-determination. ${ }^{20}$ The principle of sovereignty that gives states their 'sweeping power and rights', ${ }^{21}$ including a monopoly over the use of force in their territories, rests on this foundational understanding of the relationship between states and peoples. This has implications not only for the domestic scale of governance, but for multilateralism as well.

\subsection{Justice in Multilateralism}

The Preamble of the UN Charter, which sets out the aims and means of multilateralism in the context of the United Nations, emphasizes, above all, humanity rather than sovereignty in its focus on 'fundamental human rights', 'justice' and 'social progress'. ${ }^{22}$ Examining the deliberative processes established under the UN Charter, James Anaya notes that

statist conceptions are upheld but are made to contend with humanistic precepts and moral objectives in the authoritative multilateral processes that comprise and shape international law. And these processes are influenced not only by reformist tendencies among states, but also by non-state actors. ${ }^{23}$

Indeed, human rights, and other social and environmental movements, along with a broad array of other non-state actors form an integral component of contemporary multilateralism. Moreover, international law - much of which

20 See The Declaration on Principles of International Law concerning Friendly Relations and Co-operation among States in accordance with the Charter of the United Nations adopted by UN General Assembly Resolution 2625 (XXV) (24 October 1970).

21 Antonio Cassese, International Law, 2nd edition (Oxford University Press, Oxford, 2005), 49 .

221945 UN Charter, preamble.

23 S. James Anaya, 'Indigenous Peoples and Developments in International Law: Toward Change through Multilateralism and the Modern Human Rights Frame' in Michael G. Schecter (ed), Innovation in Multilateralism (Palgrave Macmillan, London, 1999), 223,227 . 
is born through multilateralist practice - is not exclusively crafted by or for states. It embraces different legal entities, reproduces many identities, is appropriated by states, peoples, individuals and other social actors. Different conglomerations of non-state actors belong in different ways to the international legal system - for instance, as rights holders, observers, experts and amicus curiae. In this respect, one of the major contemporary challenges of international law, and multilateralism more generally, lies in giving recognition and effect to local and transnational voices, in other words, ensuring justice in multilateralism.

Traditionally, certain groups have been more successful in claiming international law as their space through privileged access to negotiating fora. The global trade regime provides a vivid example of the stark representational and participational inequities between different non-state actors in international law-making. Multinational firms have been far more influential in shaping international trading rules elaborated under the World Trade Organization (WTO) than trade unions, environmental organizations, Indigenous Peoples, or transnational social movements. Joseph Stiglitz effectively captures these global imbalances in remarking that:

we have a system [....] in which a few institutions - the World Bank, the IMF, the WTO - and a few players - the finance, commerce, and trade ministries, closely linked to certain financial and commercial interests dominate the scene, but in which many of those affected by their decisions are left almost voiceless. ${ }^{24}$

There is a similar exclusionary dynamic to international environmental regimes reflected, for example, in the proliferation of state-developed and stateled compliance systems that can be seen as casting aside, at higher levels of governance, the peoples and places that are not only most affected by state violations of international environmental treaties, but also the least likely to be protected by state actors. ${ }^{25}$ With the exception of the tripartite governing

24 Joseph Stiglitz, Globalization and its Discontents (W.W. Norton, New York, 2002), 22.

25 Most multilateral environmental agreements (MEAs) allow non-state actors to participate in their governing body processes as observers, not full members. Moreover, compliance committees established under MEAs are generally composed of party-nominated and COP-appointed independent experts acting in their personal capacities. Most MEA compliance mechanisms can only be triggered at the request of parties or the MEA secretariat. There exist some, but very few, treaties that allow non-state actors to report on a party's non-compliance. Notable examples include the 1998 UNECE Convention on Access to Information, Public Participation in Decision-making and Access to Justice in 
body of the International Labour Organization (ILO), rule-making within most international treaty-based institutions remains a strictly state-led affair.

Nevertheless, multilateralism is continually evolving and, in some cases, becoming more inclusive. The expanding embrace of non-state actors in multilateral fora can be seen as bringing an element of justice to the international order in providing an entry point for competing and generally peripheralized visions of global governance to influence central spaces of international lawmaking. In this respect, the most significant transformations to have occurred in connection with recognition, representation and participation of non-state actors within the international legal order relate to Indigenous Peoples.

\subsection{Indigenous Peoples in Multilateralism}

The denial of Indigenous Peoples as 'sovereign legal actors' ${ }^{26}$ has been an enduring aspect of international law, since the time of early colonial encounters and treaty-making between Indigenous Peoples and Europeans. Reflecting on the naturalist, positivist and pragmatic streams of international legal jurisprudence, Anghie remarks that cultural difference, framed in early international law in the language of the 'civilised' and the 'uncivilised', has been 'crucial to the formation of sovereignty doctrine, which can be understood as providing certain cultures with all the powers of sovereignty, while excluding others.'27 He further notes that although European powers acknowledged the authority of Indigenous leaders to enter into treaties, this did not amount to recognition of their substantive sovereign equality, but merely represented an instrumental designation of 'quasi-sovereignty, for the purpose of enabling them to transfer rights, property and sovereignty.'28

Even the mid-2oth century project of dismantling colonialism prevalently ignored the effects of colonialism on the dispossession and subjugation of Indigenous Peoples, in the interest of the international community of states. In this way, Indigenous Peoples were initially excluded from the international project to legally enshrine the freedom and equality of all peoples. In the UN Declaration on the Granting of Independence to Colonial Countries and

Environmental Matters (Aarhus Convention) and the 1973 Convention on International Trade in Endangered Species of Wild Fauna and Flora (CITEs). See Nils Goeteyn and Frank Maes, 'Compliance Mechanisms in Multilateral Environmental Agreements: An Effective Way to Improve Compliance' (2011) 10 Chinese Journal of International Law, 791.

26 Patrick Macklem 'Indigenous Recognition in International Law: Theoretical Observations' (2008) 30 Mich. J. Int'l L, 177.

27 Antony Anghie, 'The evolution of international law: Colonial and postcolonial realities' (2006) 27(5) Third World Quarterly, 739, 742. 
Peoples ${ }^{29}$ self-determination - the right of 'all peoples' to 'freely determine their political status and freely pursue their economic, social and cultural development' ${ }^{30}$ - was not recognized as belonging to Indigenous Peoples. The 'saltwater thesis' ${ }^{31}$ prevented recognition of Indigenous sovereignty in colonial nations, and essentially protected the territorial integrity of states while diminishing the independent governing authority of Indigenous Peoples. ${ }^{32}$ The 'ending' of colonialism thus saw Indigenous Peoples further exposed to the hostilities of foreign power, this time cloaked as the post-colonial state. ${ }^{33}$

After the establishment of the United Nations, the very first international instrument to address the pervasive inequalities faced by Indigenous Peoples was the Indigenous and Tribal Populations Convention No. 107 (1957) of the ILO. Although the Convention was adopted with the purpose of protecting Indigenous Peoples' from discrimination and improving their socio-economic conditions, it was drafted without the direct involvement of Indigenous Peoples' representatives and set out a deeply assimilationist agenda. Since then however, understandings of the 'international community' have considerably expanded and Indigenous Peoples' movements have played a critical role in bringing multilateralism out of its traditionally statist club. As Anaya notes, Indigenous advocacy at the international scale has led to a number of 'contemporary multilateral processes that have included and been driven substantially by Indigenous Peoples' themselves. ${ }^{34}$

The UNDRIP, which enshrines the rights that 'constitute the minimum standards for the survival, dignity and well-being of the indigenous peoples of the

29 United Nations General Assembly, Declaration on the Granting of Independence to Colonial Countries and Peoples, UN Doc. A/RES/1514/XV (14 December 196o).

$30 \quad$ Ibid. See also ICCPR and ICESR, note 18.

31 The saltwater thesis (also called the blue water thesis) was incorporated into United Nations General Assembly, Resolution 1541, UN Doc. A/RES/1541(XV) (15 December 1960), amongst the principles to be respected in the international process of decolonization and the granting of independence to non-self-governing territories. It essentially limited the right to self-determination to overseas colonial territories, that is, to colonized territories that were geographically distinct (i.e. separated by sea) from their administrating colonial powers. The rule was adopted to 'preclude from decolonization procedures consideration of enclaves of indigenous or tribal peoples living within the external boundaries of independent states.' See S. James Anaya, Indigenous Peoples in International Law (Oxford University Press, Oxford, 2000), 43.

32 Joshua Nichols " "We have never been domestic": State Legitimacy and the Indigenous Question' in John Borrows, Larry Chartrand, Oonagh E. Fitzgerald et al. Braiding Legal Orders: Implementing the United Nations Declaration on the Rights of Indigenous Peoples (Centre for International Governance Innovation Press, Waterloo, 2019) 39, 43.

33 See Anghie, note 27.

34 Anaya, note 23, 224. 
world'35 is recognized as an 'Indigenous instrument'. ${ }^{36}$ At the time of its adoption, Victoria Tauli-Corpuz, Chair of the UN Permanent forum on Indigenous Issues remarked:

This Declaration has the distinction of being the only Declaration in the UN which was drafted with the rights-holders, themselves, the Indigenous Peoples. We see this is as a strong Declaration which embodies the most important rights we and our ancestors have long fought for; our right of self-determination, our right to own and control our lands, territories and resources, our right to free, prior and informed consent, among others. [...] This is a Declaration which makes the opening phrase of the UN Charter, 'We the Peoples ....' meaningful for the more than 370 million Indigenous persons all over the world. ${ }^{37}$

The UNDRIP, and the Indigenous and Tribal Peoples Convention No. 169 of the ILO (which revises the outdated but still in force Convention No. 107) are considered to 'define Indigenous peoples' rights to lands, territories and resources under international law. ${ }^{38}$ Adopted by the UN General Assembly in 2007 after two decades of negotiation, the UNDRIP consolidates existing international human rights norms ${ }^{39}$ and firmly establishes their applicability to Indigenous Peoples as a distinct, autonomous segment of the 'international public'. It is the only international instrument to explicitly address Indigenous Peoples' right to self-determination. While the ILO's work on Indigenous Peoples' rights goes back to the time of its establishment in 1919, neither of the two legallybinding treaties relating to Indigenous Peoples that were adopted by the ILO affirm the right to self-determination. ${ }^{40}$

35 UNDRIP, Art 43.

36 Victoria Tauli-Corpuz, Statement of Victoria Tauli-Corpuz, Chair of the UN Permanent Forum on Indigenous issues on the occasion of the adoption of the UN Declaration on the Rights of Indigenous Peoples (United Nations General Assembly, New York, 13 September 2007).

37 Ibid.

38 Birgitte Feiring, Indigenous Peoples' rights to lands, territories and resources (International Land Coalition, 2013) at 16. https://www.landcoalition.org/sites/default/files/documents/ resources/IndigenousPeoplesRightsLandTerritoriesResources.pdf (accessed 27/12/19).

39 See Human Rights Council, Report of the Special Rapporteur on the situation of human rights and fundamental freedoms of indigenous people, S. J. Anaya, A/HRC/9/9 (11 August 2008) at para 85 .

40 As Macklem notes, ILO C.169 'comprehends international indigenous protection as measures internal to and compatible with the sovereign authority of the State in which they are located.' See Macklem, note 26, 198. 
Certain aspects of the UNDRIP are considered international customary law. ${ }^{41}$ Despite its non-legally binding character, the UNDRIP has legal implications for national and international law, as well as regional human rights systems. ${ }^{42}$ It is precisely due to the shared failure of international, national and sub-national legal systems to embody Indigenous Peoples' interests that the UND RIP was created. Its adoption, originally supported by 143 countries, essentially denounced a centuries-long global trend of systemic injustice that, at the domestic scale, has included patronist legislation, subjugation jurisprudence, guardianship systems, forced assimilation and other forms of governmental aggression and neglect. ${ }^{43}$ As outlined in the proceeding section, the UNDRIP has implications for multilateral regimes, not just domestic legal orders.

\section{Justice in Multilateralism and International Indigenous Rights}

The UNDRIP aims to universalize Indigenous rights and to re-establish the authority that once belonged to Indigenous Peoples. Patrick Macklem notes international Indigenous rights 'speak to injustices produced by the way in which the international legal order conceives of sovereignty as a legal entitlement that it distributes among collectivities that it recognizes as States. ${ }^{\prime 4} \mathrm{He}$ posits that the central purpose of international Indigenous rights is to 'mitigate some of the adverse consequences of how international law validates morally

41 See Human Rights Council, Report of the Special Rapporteur on the situation of human rights and fundamental freedoms of indigenous people, note 39 .

42 On the UNDRIP's reception into Canadian case law and its application in the interpretation of Aboriginal rights and domestic human rights legislation, see: Nunatukavut Community Council Inc v Canada (Attorney General), 2015 FC 981 at paras 101-106; Mitchell v Minister of National Revenue, 2001 SCC 33 (CanLII) at paras 80-83; Canada (Human Rights Commission) v Canada (Attorney General), 2012 FC 445 (CanLII) at paras 350-354; Simon v Canada (Attorney General), 2013 FC 1117 (CanLII) at para 121. On regional systems, see Human Rights Council, Ten years of the implementation of the United Nations Declaration on the Rights of Indigenous Peoples: good practices and lessons learned 2007-2017, UN Doc. A/HRC/EMRIP/2017/CRP.2 (July 2017), paras 24-35. On WTO adjudication and the implications of the UNDRIP on the EU, see Michael Fakhri, 'The WTO, Self-Determination and Multi-jurisdictional Sovereignty'108 AJIL Unbound, 288, 292.

43 See M. Battiste (ed), Reclaiming Indigenous Voice and Vision (UBC Press, Vancouver, 200o); S James Anaya, Indigenous Peoples in International Law (Oxford University Press, Oxford, 2004). On Indigenous civil rights in Canada, Australia and New Zealand see Patricia Grimshaw, Robert Reynolds and Shurlee Swain, 'Paradox of ultra-democratic government' in Diane Kirkby and Catharine Coleborne (eds), Law, history, colonialism: The reach of empire (Manchester University Press, 2010).

Macklem, note 26, 209 . 
suspect colonization projects that participated in the production of the existing distribution of sovereign power. ${ }^{45}$

To this day, Indigenous Peoples are excluded from the 'international distribution of sovereignty' 46 that is performed by international law. Despite the emergence of international and domestic legal norms that recognize the leading role of Indigenous Peoples in decision-making over their life space, and the adoption of the UNDRIP which crystallizes Indigenous Peoples' selfdetermination as a constitutive aspect of the international community, most multilateral spaces continue to peripheralize Indigenous Peoples' representation even while bearing heavily on their right to self-determination. Even with UNDRIP's expanding reach into global legal systems, spaces of international legal negotiation still fail to recognize the 'parallel sovereignty' 47 of Indigenous Peoples that is enshrined in international Indigenous law. In this sense, what Macklem describes as the 'mitigating' purpose of international Indigenous rights has yet to pierce through the sphere of international legal negotiations.

Indigenous Peoples' right to self-determination, in other words, to 'control their own destinies under conditions of equality',48 must be seen as entailing both an inward (domestic) and outward (international) dimension. Even though the overall configuration of Indigenous self-determination in the UNDRIP is not explicit on the international representational dimension of Indigenous self-determination, ${ }^{49}$ its denial would be antithetical to

45 Ibid.

46 Ibid.

47 Lenzerini introduces the term to denote the shifting of 'significant sovereign prerogatives' from states to Indigenous Peoples that has emerged in light of international legal developments on Indigenous rights, and contemporary state practice recognizing Indigenous autonomy. Federico Lenzerini, 'Sovereignty Revisited: International Law and Parallel Sovereignty of Indigenous Peoples' (2006) 42 Texas International Law Journal, 155, 189.

48 S James Anaya, 'Self-Determination as a Collective Human Right Under Contemporary International Law' in Pekka Aikio and Martin Scheinin, Operationalizing the Right of Indigenous Peoples to Self-Determination (Institute for Human Rights, Turku, 200o), 3.

49 Article 4 locates Indigenous Peoples' right to self-determination in 'the right to autonomy or self-government in matters relating to their internal and local affairs, as well as ways and means for financing their autonomous functions.' Article 46(1) emphasizes the outer limits of this right and all others in providing that nothing in the UNDRIP 'may be [...] construed as authorizing or encouraging any action which would dismember or impair, totally or in part, the territorial integrity or political unity of sovereign and independent States.' Articles 46(2) and (3) provide that the exercise of UNDRIP rights are further subject to 'such limitations as are determined by law and in accordance with international human rights obligations.' Article 46(3) delineates 'the principles of justice, democracy, respect for human rights, equality, non-discrimination, good governance and good faith' as the interpretive frame for UNDRIP rights. 
the fundamental purpose of the Declaration. Theoretically, the fundamental right to self-determination links the legitimacy of any governing institutional order to how that order integrates or reflects it territorial peoples' right to freely choose their own political, economic and social systems. In this way, self-determination and state sovereignty are fundamentally linked. Their mutually constitutive relationship gives legitimacy to governmental control over territory and the peoples on that territory. In other words, it legitimates the exercise of sovereignty. Historically however, over centuries, states and the international institutions they have created have engaged in international norm-making processes that have been excessively detrimental to Indigenous Peoples, rather than integrate the latter's perspectives or interests in international relations. Condemning the $15^{\text {th }}$ century European and subsequent colonial-era denial of Indigenous sovereignty by recognizing Indigenous Peoples' right to self-determination (as UNDRIP does), while ignoring the necessary implications with respect to Indigenous authority in intergovernmental negotiations, would inevitably concentrate power over Indigenous Peoples in the very legal institutions responsible for their marginalization.

When it comes to the visibility and voice of Indigenous Peoples in international law, there has been progress, but Indigenous participation and powers of influence in international law-making are essentially still mediated by governments, and take place in state-defined structures. This affects the legitimacy of international law-making processes. In general, there remains a lack of formal mechanisms for Indigenous Peoples to exercise their selfdetermination in the elaboration of international law, and thus the scope of their participation in shaping contemporary processes of globalization remains restricted. Even within the United Nations Permanent Forum on Indigenous Issues - the UN's high-level advisory body on Indigenous issues that is composed of an equal number of government-appointed and Indigenousappointed experts - certain procedural aspects followed (such as imposed limits on plenary speaking time and seating arrangements) make visible the differential treatment of state and Indigenous actors. These are seen as reflecting 'technologies of domination that impede the efforts of Indigenous Peoples to be full and equal actors. ${ }^{50}$ At the domestic level, state-created frameworks for self-government or recognition aimed at materializing the Indigenous right to self-determination are continually challenged on the

$50 \quad$ M. Lindroth 'Paradoxes of power: Indigenous peoples in the Permanent Forum' (2011) 46

(4) Cooperation and Conflict, 543 . 
basis that they reproduce colonial relationships. ${ }^{51}$ This struggle does not disappear at the multilateral scale.

In the context of Arctic multilateralism, we have already seen tensions unfold between state and Indigenous sovereignties over their respective roles in Arctic governance. The Ilulissat Declaration, ${ }^{52}$ adopted in 2008 by the five Arctic coastal states and affirming the law of the sea (codified in the United Nations Convention on the Law of the Sea (UNCLOS) $)^{53}$ as the primary legal framework applicable to the Arctic Ocean, brought to the forefront the exclusion of Indigenous Peoples in Arctic intergovernmental deliberations. Inuit of Inuit Nunaat ${ }^{54}$ responded to the Ilulissat Declaration through their 2009 Circumpolar Inuit Declaration on Sovereignty in the Arctic ${ }^{55}$ in which they highlighted the Arctic coastal states' failure to reference 'existing international instruments that promote and protect the rights of indigenous Peoples' as part of the 'international mechanisms and international law to resolve sovereignty disputes.'

In regard to the UNCLOS regime, the lack of Inuit engagement and representation in UNCLOS processes has been raised by Arctic Indigenous representatives as contrary to UNDRIP standards. ${ }^{56}$ As Nicol notes, the UNCLOS

$5^{1} \quad$ See for example Michelle Daigle's juxtaposition of self-determination as it is lived by the Omushkegowuk Cree nation against understandings of self-determination within official state structures. M. Daigle, 'Awawanenitakik: The spatial politics of recognition and relational geographies of Indigenous self-determination' (2016) 6o(2) The Canadian Geographer, 259.

52 The Ilulissat Declaration, 28 May 2008 available at: https://cil.nus.edu.sg/wp-content/ uploads/2017/o7/2008-Ilulissat-Declaration.pdf (accessed 27/12/2019).

53 United Nations Convention on the Law of the Sea (UNCLOS), adopted 1o December 1982, entered into force 16 November 1994, 1833 UNTS 3.

54 Inuit Nunaat refers to international circumpolar homeland of the Inuit. Article 1.2. of the Inuit Circumpolar Council (ICC) Circumpolar Declaration on Sovereignty in the Arctic states 'From time immemorial, Inuit have been living in the Arctic. Our home in the circumpolar world, Inuit Nunaat, stretches from Greenland to Canada, Alaska and the coastal regions of Chukotka, Russia. Our use and occupation of Arctic lands and waters pre-dates recorded history. Our unique knowledge, experience of the Arctic, and language are the foundation of our way of life and culture.'

55 ICC, A Circumpolar Declaration on Sovereignty in the Arctic, 2009 ICC. Available at: http://iccalaska.org/wp-icc/wp-content/uploads/2016/o1/Signed-Inuit-SovereigntyDeclaration-11x17.pdf (accessed 24/12/19).

56 See Dalee Sambo Dorough, Statement at UNPFII, 12th session, New York, May 30, 2013; Charlie Watt, 'Inuit Rights to the Arctic' (7 May 2015) Law Now; Hutchins Legal, Canada's Submission to the Commission on the Limits of the Continental Shelf and the Legal Protections for Inuit Rights to the Arctic Ocean, Paper commissioned by Senator Charlie Watt, March 2014. 
framework that applies to state claims over maritime spaces is 'based upon Westphalian understandings of state sovereignty ... [it] allows that states, and only states, have the right to claim maritime territory. ${ }^{\prime 27}$ There are evident risks for the Inuit - self-identified 'maritime people'58 whose 'entire culture and identity is based on free movement over the sea and sea ice ${ }^{59}$ - as other entities perform, in Macklem's terms, a 'distribution of sovereignty' 60 under UNCLOS, in traditionally Inuit-inhabited territory.

Debates over the Ilulissat Declaration and UNCLOS reveal how international cooperative frameworks construct exclusive ad hoc clubs of agreement on the Arctic. Reflecting a more collaborative approach to governing 'global' Arctic space, the 2018 Agreement to Prevent Unregulated High Seas Fisheries in the Central Arctic Ocean ${ }^{61}$ (between Canada, United States, Russia, Norway, Denmark, China, South Korea, Japan, Iceland and the European Union) was negotiated with the direct involvement of Arctic Indigenous Peoples. The Agreement makes explicit reference to the UNDRIP and formalizes Arctic Indigenous participation as well as the role of Indigenous and local knowledge in its implementation and subsequent evolution.

\subsection{UNDRIP's Implications for International Regimes}

While the UNDRIP's affirmation of the self-determination of Indigenous Peoples is often situated in the domestic legal decision-making context, there is also an external dimension to self-determination extending to the international sphere, as argued earlier. Anaya captures the inherent unity that selfdetermination implies across multiple scales of law: '[....]peoples as such, including indigenous peoples with their own organic social and political fabrics, are to be full and equal participants at all levels in the construction and functioning of the governing institutions under which they live.'62 Evidently, the

57 H. Nicol, 'From Territory to Rights: New Foundations for Conceptualising Indigenous Sovereignty' (2017) 22 Geopolitics 794, 8 o6.

58 ICC, The Sea Ice Never Stops: Circumpolar Inuit Reflections on Sea Ice Use and Shipping in Nunaat (2014), ii. Available at: http://www.sdwg.org/wp-content/uploads/2016/o4/InuitResponse-to-AMSA-Final-Report.pdf.

59 Ibid.

6o Macklem, note 26 .

61 Agreement to Prevent Unregulated High Seas Fisheries in the Central Arctic Ocean available at: http://www.dfo-mpo.gc.ca/international/agreement-accord-eng.htm (accessed 17/12/19).

62 S James Anaya, 'The Right of Indigenous Peoples to Self-Determination in the PostDeclaration Era' in Claire Charters and Rodolfo Stavenhagen, Making the Declaration Work: The United Nations Declaration on the Rights of Indigenous Peoples (International Work Group for Indigenous Affairs, Copenhagen, 2009) (emphasis added). 
governing institutions under which Indigenous Peoples live includes international institutions, the sites through which states collectively create international legal norms. As an 'expression of the collective views of the United Nations', ${ }^{3}$ implementation of the UN DRIP cannot be seen as exclusively relating to individual states, its implementation must also be extended to international institutions.

International law has certainly come a long way in condemning its historical dismissal of Indigenous Peoples, notably by denouncing the doctrine of discovery and affirming Indigenous Peoples' right to self-determination. But our cultures of multilateralism continue to represent 'histories of colonization. ${ }^{64}$ Recognition and participation of Indigenous Peoples are by no means standardized or universalized across all international regimes whose rules bear upon Indigenous livelihoods. As climate change brings new existential challenges to Indigenous communities, it is imperative to monitor the different strands of multilateralism emerging in response to global environmental change to assess the degree to which they implement the principles enshrined in the UNDRIP. While the UNDRIP provides a clear international legal basis for centralizing Indigenous Peoples in decision-making that impacts their life space, it is evident that multiple spheres of international cooperation and legal negotiation do not yet rise to those standards. UNDRIP requires that we revisit multiple sites of international law-making, including those set out below, which are especially relevant to Arctic Indigenous Peoples in the era of climate change.

\subsection{The International Climate Change Regime}

Indigenous representation in processes established under the United Nations Framework Convention on Climate Change (UNFCCC) ${ }^{65}$ has strengthened over the last decade. Yet Indigenous Peoples' representatives remain on the peripheries of international climate change negotiations, as exemplified by the legal outcome of the Paris Agreement. ${ }^{66}$ Even with the massive mobilization of Indigenous groups at the 21st Conference of the Parties (COP) of the UNFCCC, and the widely-recognized status of Indigenous Peoples as being most acutely affected by climate change, the Paris Agreement failed to affirm Indigenous

63 ILO, Information note for ILO staff and partners: ILO Standards and the UNDRIP, Equality Team of the International Labour Standards Department (ILO, 2007).

64 Anaya, note 23, 229.

65 United Nations Framework Convention on Climate Change 31 ILM 849 (1992).

66 UNFCCC 'Decision 1/CP. 23, Adoption of the Paris Agreement' UN Doc. FCCC/CP/21/2015/ 10/Add.1 (29 January 2016), para.135. 
rights as an explicit legal dimension of the climate regime. Negotiations resulted in a preambular mention of Indigenous peoples, stating that ' $[p]$ arties should, when taking action to address climate change, respect, promote and consider their respective obligations on [...] the rights of indigenous peoples. ${ }^{\prime} 7$ Under Article 7(5) on adaptation actions, parties acknowledge adaptation actions 'should be based on and guided by [...] knowledge of indigenous peoples [...] where appropriate.'

At the same time, the Paris Agreement carves out a new role for Indigenous Peoples in international climate governance, in establishing a Local Communities and Indigenous Peoples' Platform (LCIPP) for the 'exchange of experiences and sharing of best practices on mitigation and adaptation. ${ }^{68}$ At COP 23, progress was made on the specific functions and operationalization of the LCIPP. In Decision 2/CP.23, ${ }^{69}$ the Subsidiary Body for Scientific and Technological Advice 'recalls' UNDRIP and decides 'that the overall purpose of the platform will be to [...] enhance the engagement of local communities and Indigenous peoples in the UNFCCC process.' The LCIPP is intended to serve as a knowledge portal ${ }^{70}$ and as a mechanism to 'build the capacities of Indigenous peoples and local communities to enable their engagement in the UNFCCC process. ${ }^{71}$ Decision 2/CP.23 emphasizes Indigenous autonomy and leadership in recommending:

that the processes under the platform, including its operationalization, take into account $[. .$.$] principles proposed by indigenous peoples orga-$ nizations of full and effective participation of indigenous peoples; equal status of indigenous peoples and Parties, including in leadership roles; self-selection of indigenous peoples representatives in accordance with indigenous peoples' own procedures $[\ldots]^{72}$

The Decision clearly reflects progress towards a more robust implementation of the UNDRIP within the UNFCCC framework, in the sense that it advocates Indigenous Peoples' equality in the emergent multilateral process. Graeme

67 Preamble, Paris Agreement.

68 UnfCCC 'Decision 1/CP. 23, Adoption of the Paris Agreement' UN Doc. FCCC/CP/21/2015/ 10/Add.1 (29 January 2016), para.135.

69 UNFCCC 'Decision 2/CP.23, Local communities and indigenous peoples platform,' UN Doc. FCCC/CP/2017/11/Add.1 (8 February 2018) [Hereinafter the Decision].

70 Ibid, [6(a)].

71 Ibid, [6(c)].

72 Ibid, 8 (emphasis added). 
Reed and Tonio Sadik remark that even though Indigenous Peoples' representation and participation in the negotiation process of the Decision was 'unprecedented', the Decision explicitly qualifies the facilitative working group established under the LCIPP as a non-negotiating body, and neither of the processes currently foreseen under the LCIPP grant decision-making authority to Indigenous Peoples in what remains an entirely 'party-driven' UnfCCc. ${ }^{73}$ This state-centric framework not only constrains the scope of Indigenous participation and authority, it entrenches a specific cultural model of discourse and decision-making in which Indigenous knowledge is marginalized and its relevance in shaping the climate regime is exclusively determined through a 'Western' lens. ${ }^{74}$

Underscoring that the LCIPP establishes an unprecedented 'formal, permanent, and distinct space created for Indigenous Peoples within the UNFCCC, ${ }^{75}$ Ella Belfer et al. also draw attention to concerns expressed by Indigenous participants engaged in the UNFCCC over the possible risk that 'operationalization of the platform is used by Parties to silo Indigenous voices to one body or reduce access to different stages of negotiations. ${ }^{76}$

While Indigenous rights, autonomy and knowledge continue to be increasingly validated under the emergent framework, the ongoing development of the Paris Agreement illustrates the longstanding imbalances within the international community, where Indigenous voices 'are not understood to have a role $[. .$.$] beyond that of a general consultative nature, arguably only where$ convenient. ${ }^{77}$ For example, the Inuit Circumpolar Council (ICC), an international non-governmental organization representing Inuit of Alaska, Canada, Greenland and Russia with consultative status at the UN has, for several years,

73 Graeme Reed and Tonio Sadik, Operationalizing the Local Communities and Indigenous Peoples' Platform: A Step in the Right Direction (4 December 2017) CIG I. Available at: https:// www.cigionline.org/articles/operationalizing-local-communities-and-indigenouspeoples-platform-step-right-direction.

74 See Claudia Comberti, Thomas Thornton and Michaela Korodimou, Addressing Indigenous Peoples' Marginalisation at International Climate Negotiations: Adaptation and Resilience at the Margins, Working paper, Environmental Change Institute Environmental Change Institute Oxford University, (2016) available at: https://www.eci.ox.ac.uk/publications/policy-brief-pdf/20161116_IP-marginalisation_CComberti.pdf (accessed 18/4/ 2o); see also Ella Belfer, James D. Ford, Michelle Maillet et al., 'Pursuing an Indigenous Platform: Exploring Opportunities and Constraints for Indigenous Participation in the UNFCCC' (2019) 19 Global Environmental Politics, 12.

75 Belfer, Ford, Maillet et al., ibid, 27.

76 Ibid, 27 .

77 H Nicol 'Nunavut, Sovereignty and the Future of Arctic Peoples' Involvement in Regional Self-Determination' (2013) 37 The Northern Review 127, 136. 
been urging parties to the UNFCCC to acknowledge the significant climateforcing role of black carbon and to develop measures to mitigate black carbon emissions entering the Arctic - 70 percent of which come from outside the Arctic region. ${ }^{78}$ These concerns have not been addressed under UNFCCC processes to date and the overwhelming majority of UNFCCC members ignore the issue of black carbon emissions in their reporting commitments under the Paris Agreement.

Many Indigenous delegates' experiences of UNFCCC meetings and working processes alert us to how accreditation, financial resources, language and translation issues, and spatial organization at COP s pose significant and persistent material constraints that, in addition to 'objectification' and 'tokenism', gravely inhibit meaningful Indigenous participation within the international climate regime. ${ }^{79}$ While informal spaces for networking and influencing party positions do exist, and, to a certain degree, help minimize the dispossessing effects of various constraints on Indigenous representation and participation in the UNFCCC, ${ }^{80}$ it is evident that rights enshrined in the UNDRIP support recognition of Indigenous Peoples' full party status.

\subsection{The International Maritime Organization (IMO)}

The IMO is a specialized UN agency composed of 173 member states. It is responsible for regulating global shipping and the prevention of marine pollution by ships. As such, it is an institution that produces global legal standards which profoundly impact the life space of Arctic Indigenous Peoples. In anticipation of increased shipping in the Arctic under climate change, the IM began developing the Polar Code, which contains special rules for vessels operating in Polar waters. Even though negotiations began in 2009, and the Polar Code entered into force at the start of 2017, Arctic Indigenous Peoples played no sustained role in this entire process. ${ }^{81}$ Dalee $S$ Dorough cites several

78 ICC, Inuit Call for Action from Global Leaders at UNFCCC COP 21 in Paris, France (2015); ICC, Inuit Call on Global Leaders at UNFCCC COP 18 in Doha, Qatar: Making the most of the 20132015 review and the second commitment period under the Kyoto Protocol, 5 December 2012. Available at: http://iccalaska.org/wp-icc/wp-content/uploads/2016/o3/ICC-Statement_ UNFCCC-COP18.pdf (accessed 27/12/19); Arctic Monitoring and Assessment Program, Black Carbon and Ozone as Arctic Climate Forcers. Summary for Policy Makers (AMAP, 2015).

79 See Belfer, Ford, Maillet et al. and Comberti, Thornton and Korodimou, note 74.

80 Ibid.

81 Dalee S Dorough 'The Rights, Interests and Role of the Arctic Council Permanent Participants' in Robert Beckman, Tore Henriksen, Kristine Dalaker Kraabel et al, Governance of Arctic Shipping: Balancing Rights and Interests of Arctic States and User States (Brill Nijhoff, Leiden, 2017) 68, 98. 
factors that led to the Inuit Circumpolar Council's decision not to engage in the process; these included financial and human resource limitations; 'procedural rules that center on a heavily state- or party-driven process creating limited ability for Indigenous peoples' representatives to influence the subject matter'; 82 and 'environmental NGO s that attempted to capitalise on the concerns and agenda of Indigenous peoples in the context of marine environmental protection[...].83

As a result, Indigenous knowledge and science on the marine ecosystem were largely ignored in a global rule-making process directly impacting their traditionally occupied lands, cultural integrity and food security. Under the current version of the Polar Code many major socio-environmental global shipping issues that are linked to Inuit self-determination and food security remain unaddressed, including black carbon emissions and grey water discharge.

The IMO only began interacting directly with Arctic Indigenous groups in 2016, when the non-governmental organization (NGO) World Wildlife Fund (an accredited observer at the IMO) invited a delegation of Indigenous leaders from Canada, Russia and the United States to the 7oth session of the Imo's Marine Environment Protection Committee (MEPC) to meet with the IMO Secretary General and to address IMO members during a panel discussion at IMO headquarters in London. ${ }^{84}$ At the $72 n d$ and 73 rd sessions of its MPEC, the IMO considered the adoption of greenhouse gas (GHG) emissions reduction targets and heavy fuel oil (HFO) restrictions - two issues that gravely impact Inuit livelihoods. A few months earlier, the 13th General Assembly of the Inuit Circumpolar Council (ICC) had adopted the Utkiagvik Declaration ${ }^{85}$ stressing the importance of phasing out HFO to support food security in Inuit communities. One of the major outcomes of the 73rd session was that ImO members agreed to commence work towards banning the use and carriage of HFO in the Arctic, converging with Inuit demands.

At its meeting in early 2019, the Imo Sub-Committee on Pollution Prevention and Response (PPR) agreed on a draft methodology for analysing impacts of an HFo ban in the Arctic. The methodology adopted integrates concerns

\footnotetext{
82 Ibid.

83 Ibid.

84 See Chamber of Shipping, IMO Secretary General meets with Arctic Indigenous Leaders (28 October 2016) available at: http://www.cosbc.ca/index.php?option=com_ k2\&view=item\&id=2948:imo- secretary-general-meets- with-arctic-indigenousleaders\&Itemid $=292($ accessed 27/12/19).

85 ICC, Utkiagvik Declaration (ICC, 2018), available at: https://www.arctictoday.com/wpcontent/uploads/2018/o7/2018-Utigavik-Declaration.pdf (accessed 17/12/19).
} 
advanced by Arctic Indigenous groups, in requiring specific analyses which include 'assessment of the costs to Arctic indigenous and local communities and industries' and 'assessment of the benefits of an $\mathrm{HFO}$ ban to Arctic indigenous and local communities and ecosystems. 86 The ICC was represented at this meeting by ICC Canada Vice-President Lisa Koperqualuk who drew attention to the significance of the UNDRIP in the opening plenary:

The UN Declaration on the Rights of Indigenous Peoples recognizes our cultural rights, economic rights, Indigenous knowledge, and selfdetermination. The PPR sub-committee must ensure that our communities are not negatively impacted, culturally, socially and economically by decisions here. We can achieve this by engaging Inuit communities during this important work towards a ban on the use and carriage of HFO's in Arctic waters. 87

These early IMO deliberations on the issue of banning HFO in the Arctic signal the emergence of a new multilateral consciousness, with respect to the agency's engagement with Arctic Indigenous Peoples and the UNDRIP. At the same time, it is imperative to note that to date, Arctic Indigenous Peoples have only been able to participate in IMO processes as observers through their affiliation with accredited NGO delegations, and they have no formal role in negotiations. The IMO's procedures for observer accreditation rely on IMO member state determinations of which international NGO s are 'truly international', 'demonstrate considerable expertise' and 'have the capability to make a substantial contribution to the work of IM0.' 88

Evidently, when it comes to Indigenous Peoples' organizations, such a stateled process of recognition and validation stands starkly in contrast with the standards for state-Indigenous relations contained in the UNDRIP. It allows Iмо member states the power to deny Arctic Indigenous Peoples' organizations consultative status in the process of creating regulatory frameworks that disproportionally impact Arctic Indigenous food security and cultural integrity.

86 Imo, Meeting Summary of the Sub-Committee on Pollution Prevention and Response (PPR 6), 18-22 February 2019, available at http://www.imo.org/en/MediaCentre/ MeetingSummaries/PPR/Pages/PPR-6th-Session.aspx (accessed 17/12/19).

87 ICC Canada, ICC Canada Brings Inuit Message to London IMO Meeting: Time to Ban HFO's in Arctic Shipping (21 February 2019) available at: https://www.inuitcircumpolar.com/ press-releases/icc-canada-brings-inuit-message-to-london-imo-meeting-time-to-banhfos-in-arctic-shipping/ (accessed 17/12/19).

88 IMO, Member States, IGOs and NGOs, available at: http://www.imo.org/en/About/ Membership/Pages/Default.aspx (accessed 17/12/19). 
NGO s with IMO observer status primarily represent a broad range of industry interests and, under established IMO practice, the global shipping industry is heavily involved in the treaty-drafting process. ${ }^{89}$ IMO observers representing environmental interests have a weaker influence in the negotiation process as compared to those representing the global shipping industry, as reflected by the final outcome of the Polar Code. ${ }^{90}$

Arctic Indigenous representatives have demanded 'consistent Indigenous representation'91 at the IMO. As discussed above, the IMO's emerging work plan on an HFO ban appears to explicitly integrate, for the first time ever, Arctic Indigenous concerns into IMO process. To what degree this approach will extend to other critical issue areas - such as black carbon emissions and grey water discharge, remains to be seen. Without the official recognition and participation of Arctic Indigenous Peoples in IMo processes, it is possible that even environmentally progressive achievements under the IMO are implemented in a manner that marginalizes Indigenous Peoples' interests. One of the lessons of early experiments in multilateral climate governance has been that without meaningful participational rights, climate responses may further threaten already highly vulnerable populations, interfering with the fulfillment of their fundamental human rights. ${ }^{92}$

The discussion above illustrates that to implement the UNDRIP, international institutions must look beyond the exclusionary traditions of multilateralism and dominant inward-looking interpretations of Indigenous Peoples' right to self-determination. In essence, realizing multilateral justice for Indigenous Peoples requires that we recognize what Macklem has defined as UNDRIP's mitigating purpose, and make space for both state and Indigenous sovereignties in global governance. One way to think about how to make international

89 A Chircop 'The IMO, its Role under UNCLOS and its Polar Shipping Regulation' in Robert Beckman, Tore Henriksen, Kristine Dalaker Kraabel et al, Governance of Arctic Shipping: Balancing Rights and Interests of Arctic States and User States (Brill Nijhoff, Leiden, 2017), 117.

$90 \quad$ Ibid.

91 Nunatsiaq News, Pressure's on UN shipping agency to embrace heavy fuel oil ban (April 12, 2018), available at: http://nunatsiaq.com/stories/article/65674pressures_on_un_shipping_agency_to_embrace_heavy_fuel_oil_ban/(accessed 17/12/19).

92 J Schade and W Obergassel, 'Human Rights and the Clean Development Mechanism' (2014) 27 Cambridge Review of International Affairs, 717. 
law more inclusive is to consider how to break out of the deadlock of observer status and to integrate models of equal membership, participation and representation of Indigenous representatives within negotiating bodies. In this regard, the ICC's transnational Arctic Indigenous activism provides insight into what sovereignty decentred from the state looks like, and the impact it may have on international law.

\subsection{The Inuit Circumpolar Council}

Since the 1970s, Inuit have been formally organized across state borders, advocating for the expansion of international law in the Arctic 'in the context of seeking increased self-determination. ${ }^{93}$ The ICC was founded with a vision to 'strengthen unity among the Inuit of the circumpolar region, to promote Inuit rights and interests on an international level' ${ }^{4}$ and to 'ensure Inuit participation in political, economic and social institutions which [...] the Inuit, deem relevant. ${ }^{95}$ The ICC's transboundary activism has profoundly influenced international treaty-making on persistent organic pollutants (POP s) and mercury. ${ }^{96}$ These treaties are the first and only areas of international law to explicitly recognize that the food security and self-determination concerns of Arctic Indigenous groups are threatened by globally-produced contaminants.

In terms of transnational Arctic Indigenous cooperation, the ICC was preceded by the Saami Council, established in 1956 by Saami communities in Finland, Russia, Norway and Sweden. The ICC is thus an Indigenous institution that predates any formal cooperation between all Arctic states. This historical aspect of international cooperation in the Arctic has led to the observation that 'trans-Arctic diplomacy was [...] pioneered not by the six governments of the adjacent states, but by a non-governmental 'trans-national' association of native peoples. ${ }^{\prime 97}$ The ICC's vision and transboundary constitution makes it clear that statist perspectives of self-determination and the right to cultural integrity, which fail to recognize Indigenous authority over territory or resources as existing beyond domestic governance arrangements, do not provide an effective means to the realization of these legal concepts as understood by the

93 H Selin and N E Selin 'Indigenous Peoples in International Environmental Cooperation: Arctic Management of Hazardous Substances' (2008) 17 RECIEL, 72, 75.

94 ICC, Charter $\operatorname{Art} 3(\mathrm{a})(\mathrm{b})$, available at https://www.inuitcircumpolar.com/icc-international/ icc-charter/ (accessed 18/04/20).

95 Ibid. Art 3 (c).

96 Inuit Tapiriit Kanatami (ITK), Inuit Priorities for Canada's Climate Strategy: A Canadian Inuit Vision for Our Common Future in Our Homelands (ITK, 2016) 41.

97 L.P. Bloomfield, 'The Arctic Last Unmanaged Frontier' (1981) 6o Foreign Affairs 87, 90 cited in Selin and Selin, note 93. 
Inuit. Self-determination, as understood by the Inuit of Inuit Nunaat, exists beyond the territorial integrity of the state. ${ }^{98}$

During its existence, the ICC has emerged as a powerful transnational Indigenous institution perpetuating a distinctly Indigenous concept of sovereignty that does not involve seeking statehood, but instead, brings to global attention the critical external dimension of self-government and autonomy of Indigenous Peoples in the world of international cooperation. In unifying Inuit peoples across several state borders, advocating on their behalf in the international legal sphere, and emphasizing that use and occupation of the Arctic and sub-Arctic by Inuit of Inuit Nunaat 'transcends political boundaries', 99 the ICC disrupts state-based conceptions of both sovereignty and self-determination.

The ICC has obtained observer status at the UN and permanent participant status in the Arctic Council, the high-level intergovernmental forum established by the eight Arctic states to foster cooperation on common Arctic issues with a focus on 'sustainable development and environmental cooperation.'100 Despite the ICC's highly visible role in international environmental negotiations and its critical contribution to the development of international treaties on POP s and mercury, these instruments share the common limitations of other international legal instruments in that non-state actors are not granted authority in decision-making, implementation or monitoring owing to the limitations of their observer status.

\subsection{The Arctic Council}

Within the Arctic Council, six Arctic organizations of Indigenous Peoples are recognized as permanent participants and granted active participation and full consultation rights in all aspects of the Council's work. Dorough notes that despite not having formal voting power, the permanent participants exercise 'extraordinary influence over all issues for consideration due to the consensus decision-making approach of the Arctic Council.'101 Timo Koivurova and Leena Heinämäki interpret the status of permanent participants as giving rise to a 'de facto power of veto should they all reject a particular proposal.'102 From this perspective, the Arctic Council surpasses the epistemological limitations

$98 \quad$ ICC Charter, preamble.

99 ICC Charter, preamble.

100 Arctic Council, Ottawa Declaration establishing the Arctic Council (September 19, 1996), Art 1(a).

101 Dorough, note 81, 82.

102 Timo Koivurova and Leena Heinämäki "The Participation of Indigenous Peoples in International Norm-making in the Arctic" (2006) 42 Polar Record 101, 104. 
of the traditional international legal order in that the inclusion of Indigenous transboundary representation and authority in decision-making removes the state as the definitional reference point of sovereignty in international relations. In essence, the centralization of Arctic Indigenous representation within the Arctic Council brings this particular multilateral space closer to the full and equal participation called for under the UNDRIP. It provides useful insight as to how spaces of international negotiation can better integrate Indigenous knowledge systems, science, and leadership.

The Arctic Council does not have the status of a legal organization and even though it has produced three international legally binding agreements in recent years, it falls outside the traditional understanding of an international legal institution. ${ }^{103}$ For Koivurova and Heinämäki, the experience of the Arctic Council shows that soft law possesses a 'revolutionary potential'104 for Arctic organizations of Indigenous groups, as a norm-making method that is not dependent on international law's state-based structures. In many ways, the Arctic Council is reflective of an intergovernmental platform that makes a step towards mitigating state sovereignty in recognizing, at the very least implicitly, the parallel sovereignty of Indigenous groups that is embodied in contemporary international Indigenous rights.

Questions of who belongs in the 'world community', who doesn't, and who decides, permeate all international legal spaces and affect Indigenous Peoples uniquely. The adoption of the UNDRIP obliges us to investigate injustices and imbalances of power engrained in the making of international law, and in practices of contemporary multilateralism more broadly. Through an examination of international legal instruments relevant to Arctic climate change, this Chapter has highlighted how the UNDRIP's implementation at the global scale requires deep institutional reform across multilateral spaces.

The significance of Indigenous sovereignty and self-determination (the latter term being understood as the minimum scope of Indigenous sovereignty

103 In the Ottawa Declaration establishing the Arctic Council, the Arctic Council member states define the Arctic Council in non-legal terms as an intergovernmental 'high-level forum', and furthermore underscore its 'political significance'. See Ottawa Declaration, note 100 .

104 Ottawa Declaration, note, 100, 103. 
in international customary and treaty law) cannot be ignored. Historically, the structural imbalances and interpretive styles of our international legal order have benefited the exploitation of human and environmental resources for economic purposes in the interests of states and to the detriment of Indigenous Peoples. Although ever-present in the international sphere, and influential in international-norm creation on certain issues, Indigenous Peoples have never been able to crystallize their full participation. ${ }^{105}$

The international order thus continues to grapple with its state-centric limitations. In all international institutions, Indigenous Peoples are still subject to the ultimate decision-making authority of states as their involvement in international cooperation is, above all, mediated and structured by governments. This state-centricity represents an ontological limitation of international law that bears heavily on its legitimacy, curtails the full and equal participation of Indigenous Peoples, and restricts the role of Indigenous knowledge and science in the production of international law. Circuits of international legal negotiation and exchange engage with Indigenous Peoples' representatives as observers not parties, producing narrowed views of what constitutes 'the global' and effacing fundamental differences between Indigenous peoples' organizations and other non-state actors. The most important of these differences is Indigenous Peoples' historic sovereignty in international relations, and existing forms of Indigenous sovereignty as evoked by the nation-to-nation relationship that characterizes legal realities between Indigenous Peoples and states in a number of national contexts.

The Arctic Council, in granting Indigenous peoples' representative organizations 'full consultation rights on all negotiations and decisions', should serve as inspiration for collective rule-making on global problems. Another inspiring example is the International Union for the Conservation of Nature that, in 2016, created a new membership category for the first time in its history to enable the full and equal participation of Indigenous Peoples as members of the

105 T. Koivurova \& L. Heinämäki supra note 102. See also Koivurova's discussion on state responses to Saami and Inuit agency in international relations and other practices of external self-determination in T Koivurova 'Redefining Sovereignty and Self-Determination through a Declaration of Sovereignty: The Inuit Way of Defining the Parameters for Future Arctic Governance' in I. Ziemele et al Making Peoples Heard: Essays on Human Rights in Honour of Gudmundur Alfredsson (Brill Nijhoff, Leiden, 2011). On the participation of Indigenous groups within the climate regime, see E.A. Kronk Warner, 'South of South: Examining the International Climate Regime from an Indigenous Perspective' in S. Alam et al. (eds). International Environmental Law and the Global South (Cambridge University Press, 2015), 451. 
Union. ${ }^{106}$ The 2018 Agreement to Prevent Unregulated High Seas Fisheries in the Central Arctic Ocean mentioned earlier also reflects an evolution towards the deeper integration of UNDRIP in multilateral law-making. These examples hint us towards possibilities for how to bring to life 'a theory of resistance into international law', ${ }^{107}$ in the sense of correcting the wrongful historical dismissal of Indigenous Peoples as sovereigns, by duly recognizing their equal place and authority in the contemporary world-making craft of multilateralism. These institutions and agreements encourage further reflection on how to approach collective rule-making on global environmental problems in a manner that brings international relations out of the statist lens and closer to the fulfillment of international Indigenous rights.

\section{Acknowledgement}

The author wishes to thank the Four Societies. She expresses her gratitude to the American Society of International Law and to the Academy of Finland (decision \#314767) for financial support.

\section{Select Bibliography}

S. James Anaya, Indigenous Peoples in International Law (OUP, 2004).

S. James Anaya and Sergio Puig, 'Mitigating State Sovereignty: The Duty to Consult with Indigenous Peoples' (2017) 67 University of Toronto L. J. 435.

Antony Anghie 'The evolution of international law: Colonial and postcolonial realities' (2006) 27(5) Third World Quarterly, 739.

Ella Belfer, James D. Ford, Michelle Maillet et al. 'Pursuing an Indigenous Platform: Exploring Opportunities and Constraints for Indigenous Participation in the UNFCCC' (2019) 19(1) Global Environmental Politics, 12.

John Borrows, Larry Chartrand, Oonagh E. Fitzgerald, et al. Braiding Legal Orders: Implementing the United Nations Declaration on the Rights of Indigenous Peoples (Centre for International Governance Innovation Press, Waterloo, 2019).

106 IUCN,IUCNCongressboostssupportforIndigenouspeoples'rights(10September,2016), available at https://www.iucn.org/news/secretariat/2016o9/iucn-congress-boosts-supportindigenous-peoples'-rights (accessed 18/4/20).

107 Balakrishnan Rajagopal 'International Law and Social Movements: Challenges of Theorizing Resistance' (2003) 41 Columbia Journal of Transnational Law, 397. 
Claudia Comberti, Thomas F. Thornton and Michaela Korodimou, Addressing Indigenous Peoples' Marginalisation at International Climate Negotiations: Adaptation and Resilience at the Margins (2016) Working paper, Environmental Change Institute, University of Oxford.

Dalee S. Dorough, 'The Rights, Interests and Role of the Arctic Council Permanent Participants' in Robert Beckman, Tore Henriksen, Kristine Dalaker Kraabel et al, Governance of Arctic Shipping: Balancing Rights and Interests of Arctic States and User States (Brill Nijhoff, Leiden, 2017) 68.

Inuit Circumpolar Council, A Circumpolar Declaration on Sovereignty in the Arctic (2009) ICC.

T. Koivurova and Leena Heinämäki, 'The Participation of Indigenous Peoples in International Norm-making in the Arctic' (2006) 42 Polar Record 101.

Timo Koivurova, 'Redefining Sovereignty and Self-Determination through a Declaration of Sovereignty: The Inuit Way of Defining the Parameters for Future Arctic Governance' in Eide Asbjørn, Jakob Th. Möller and Ineta Ziemele (eds), Making Peoples Heard: Essays on Human Rights in Honour of Gudmundur Alfredsson (Brill Nijhoff, Leiden, 2011) 493.

Federico Lenzerini 'Sovereignty Revisited: International Law and Parallel Sovereignty of Indigenous Peoples' (2006) 42 Texas International Law Journal, 155.

Marjo Lindroth, 'Paradoxes of power: Indigenous peoples in the Permanent Forum' (2011) 46 Cooperation and Conflict, 543 .

Patrick Macklem, 'Indigenous Recognition in International Law: Theoretical Observations' (2008) 3o Mich. J. Int'l L, 177.

Heather N. Nicol, 'From Territory to Rights: New Foundations for Conceptualising Indigenous Sovereignty' (2017) Geopolitics 794.

Heather N. Nicol, 'Nunavut, Sovereignty and the Future of Arctic Peoples' Involvement in Regional Self-Determination' (2013) 37 The Northern Review 127.

Henrik Selin and Noelle Eckley Selin, 'Indigenous Peoples in International Environmental Cooperation: Arctic Management of Hazardous Substances' (2008) $17 R E$ CIEL 72.

Jessica Shadian, 'Of Whales and Oil: Inuit Resource Governance and the Arctic Council' (2013) 49 Polar Record 392. 